\title{
Development of Apothecia from Stone Fruit Infected and Stromatized by Monilinia fructicola in California
}

\author{
Brent A. Holtz, University of California Cooperative Extension, 328 Madera Ave., Madera 93637, Themis J. \\ Michailides and Chuanxue Hong, Department of Plant Pathology, University of California-Davis, Kearney Agri- \\ cultural Center, Parlier 93648
}

\begin{abstract}
Holtz, B. A., Michailides, T. J., and Hong, C. X. 1998. Development of apothecia from stone fruit infected and stromatized by Monilinia fructicola in California. Plant Dis. 82:1375-1380.

Apothecia were produced in the orchard, lath house, and laboratory from peach and nectarine fruit infected and stromatized by Monilinia fructicola. Fully stromatized "mummies" and nonstromatized infected fruit were placed in the orchard either on the soil surface or buried to a depth of 2 to $3 \mathrm{~cm}$. Mummies were placed in the orchard at monthly intervals from August to February in 1993-94 and 1994-95. Nonstromatized infected fruit, which were fleshy and decomposed rapidly, were soon unavailable and were only placed in the orchard in August and September. Apothecia developed in February and early March only from mummies that were placed in the orchard in either October, November, or December. Mummies placed in the field in August, September, January, and February did not produce apothecia. Leaving mummies on the soil surface versus burying them 2 to $3 \mathrm{~cm}$ did not affect the development of apothecia. Apothecia were never produced from nonstromatized or recently-infected (fleshy) fruit. In the laboratory, apothecia were only produced from mummies that were partially buried in moist sand and stored without light at $2^{\circ} \mathrm{C}$ and $>97 \%$ relative humidity (RH) for more than 8 weeks prior to incubation for 2 weeks $\left(12,15\right.$, or $\left.20^{\circ} \mathrm{C}\right)$ with a 12-h photoperiod. Mummies that were incubated at $>97 \%$ RH for less than 8 weeks or incubated at $<90 \%$ RH never produced apothecia when stored at $2^{\circ} \mathrm{C}$ and then transferred to warmer temperatures with light. In orchard experiments, apothecia were only observed in plots with nondisturbed orchard floor vegetation; whereas no apothecia were found in either herbicide-treated or rototilled plots. Apothecia in the San Joaquin Valley were only produced from mummies that were subject to an 8-week or greater cold-temperature incubation while in contact with soil.
\end{abstract}

Additional keywords: brown rot, primary inoculum, Prunus persica

Brown rot, caused by Monilinia fructicola (G. Wint.) Honey, is the greatest cause of reduced yields and economic losses to stone fruit (Prunus) growers in California. Despite extensive fungicide programs, if weather conditions are wet and cool in the spring, brown rot can attain epidemic levels. Losses occur from blossom infection and rotting of green fruit in spring, and from rotting of mature fruit in summer and after harvest during storage and transport $(6,27)$.

M. fructicola can survive the winter as mycelium in rotted fruit, which can produce either conidia or a sclerotial mat or endostroma from which apothecia appear as the host blossoms in the spring $(6,27)$. Tufts of buff-colored conidia are produced on the blighted flowers a few days after infection (6). These conidia can serve both as secondary inoculum, initiating other blossom infections, and as an inoculum

Corresponding authors: B. A. Holtz and T. J. Michailides; E-mails: baholtz@ucdavis.edu and themis@uckac.edu

Accepted for publication 10 September 1998.

Publication no. D-1998-1023-01R

(C) 1998 The American Phytopathological Society source for both the incipient infection of green fruit $(5,17,22)$ and the infection of susceptible ripe fruit later in the season $(6,24,27)$. Both brown rot fungi, M. fructicola and M. laxa (Aderhold \& Ruhland) Honey, produce conidia throughout the season in previously infected plant parts (peduncles, cankers, and buds) if conditions are favorable $(1,6,11,21,27)$, but in California, only $M$. fructicola has been found to overwinter and produce apothecia with ascospores $(14,19)$.

With the discovery in 1936 that apothecia were produced in abundance from brown rot infected peach mummies in an important peach growing region of California (14), and proof of ascospore pathogenicity $(20,30)$, researchers speculated that mummies and apothecia were important in the epidemiology of brown rot and served as a primary source of inoculum in the spring $(5,14,19,20,22,26)$. Unfortunately, efforts were not further pursued in California to determine the importance of apothecia in the epidemiology of brown rot or the conditions that favor the development of apothecia. Most brown rot control programs rely on fungicide sprays $(6,27)$, and in some cases fungicide resistance has been reported $(25,28)$.
In California, apothecia of M. fructicola were observed in stone fruit orchards during bloom from 1994 through 1997 (12,19) and were shown to produce abundant ascospores (18). Conidia were never found sporulating on mummies from the previous season, either on trees or on the orchard floor (19). Apothecia were commonly found on orchard floors with natural vegetation or cover crops, which may create a habitat that reduces desiccation. Apothecia were rarely found in orchards that were recently disked, rototilled, or completely sprayed with herbicide prior to spring bloom $(15,18)$. More apothecia were also found on the shaded northern sides of trees than on the southern sides (19).

Mummies are infected fruit that have had an 8- to 16-week period in the summer to form stromata (pseudosclerotia or entostroma, resistant fungal tissue intertwined with decayed fruit), and that are hard and not easily decomposed $(2,29,31,32)$. The stromata give rise to apothecia under conducive conditions. In Japan, researchers $(31,32)$ have shown that in order for fruit infected by $M$. fructicola to produce apothecia, they must first become stromatized or produce mature stromata, a process that involves a 4- to 8week period at 15 to $20^{\circ} \mathrm{C}$, another 4- to 8 week period at 20 to $30^{\circ} \mathrm{C}$, and then 3 to 4 months at 0 to $15^{\circ} \mathrm{C}$.

This research was undertaken to examine the conditions under which infected fruit from the San Joaquin Valley become stromatized by $M$. fructicola and later produce apothecia, in order to design and implement cultural controls most likely to disrupt the formation of apothecia, which could be important in the epidemiology of brown rot. Different orchard floor management practices were also studied to determine if they could influence the development of $M$. fructicola apothecia and the incidence of brown rot.

\section{MATERIALS AND METHODS}

Production of apothecia in orchards. Mummies and nonstromatized, infected fruit were collected from a 33-ha peach (Prunus persica (L.) Batch cv. Babcock) orchard in Reedley, California. The grower cooperator removed mummies and nonstromatized, infected fruit for our experiments, and we monitored the number removed from 1993 to 1997. Nonstromatized or recently infected fresh fruit were taken 
from trees or the ground shortly before or after harvest (August to September), and mummies were collected from trees in October and either placed in the orchard or stored until placement at $2^{\circ} \mathrm{C}$ and $<90 \%$ relative humidity $(\mathrm{RH})$. Infected fruit collected in October were considered mummies because they had sufficient incubation time to form stromata or entostroma (32). 4,800 nonstromatized, infected fruit were placed in a randomized manner in an experimental peach (cv. Elegant Lady) orchard at the Kearney Agricultural Center (KAC), either on the soil surface or buried, from August to February in both 1993-94 and 1994-95. Approximately 400 mummies were placed next to each of six trees each month. The mummies were placed under the north side of the tree canopy, half on the soil surface and half buried 2 to 3 $\mathrm{cm}$ below the surface. Nonstromatized, infected fruit, which decomposed rapidly and were soon unavailable, were placed in
Approximately 16,800 mummies and

the orchard in the same manner only in August and September. Plots where both mummies and nonstromatized, infected fruit were placed were examined twice weekly in the spring from 1 February to 15 March for apothecia. Data on the percentage of mummies and nonstromatized, infected fruit that produced apothecia were subjected to ANOVA with SAS software procedures (SAS Institute, Cary, NC), and treatment means were separated by Fisher's least significant difference test (LSD) at $P=0.05$. In 1995-96, only mummies were randomly placed in orchard plots in December, approximately 400 by each of 36 trees, which were assessed for brown rot. Weather data were obtained from the Parlier.A station, California Irrigation Management Information System.

Production of apothecia in a lath house. In 1994-95 and 1995-96, approximately 5,400 mummies were placed in black plastic planting flats $(52 \times 36 \times 10$ $\mathrm{cm})$ either on the soil surface, partially buried (half buried), or completely buried

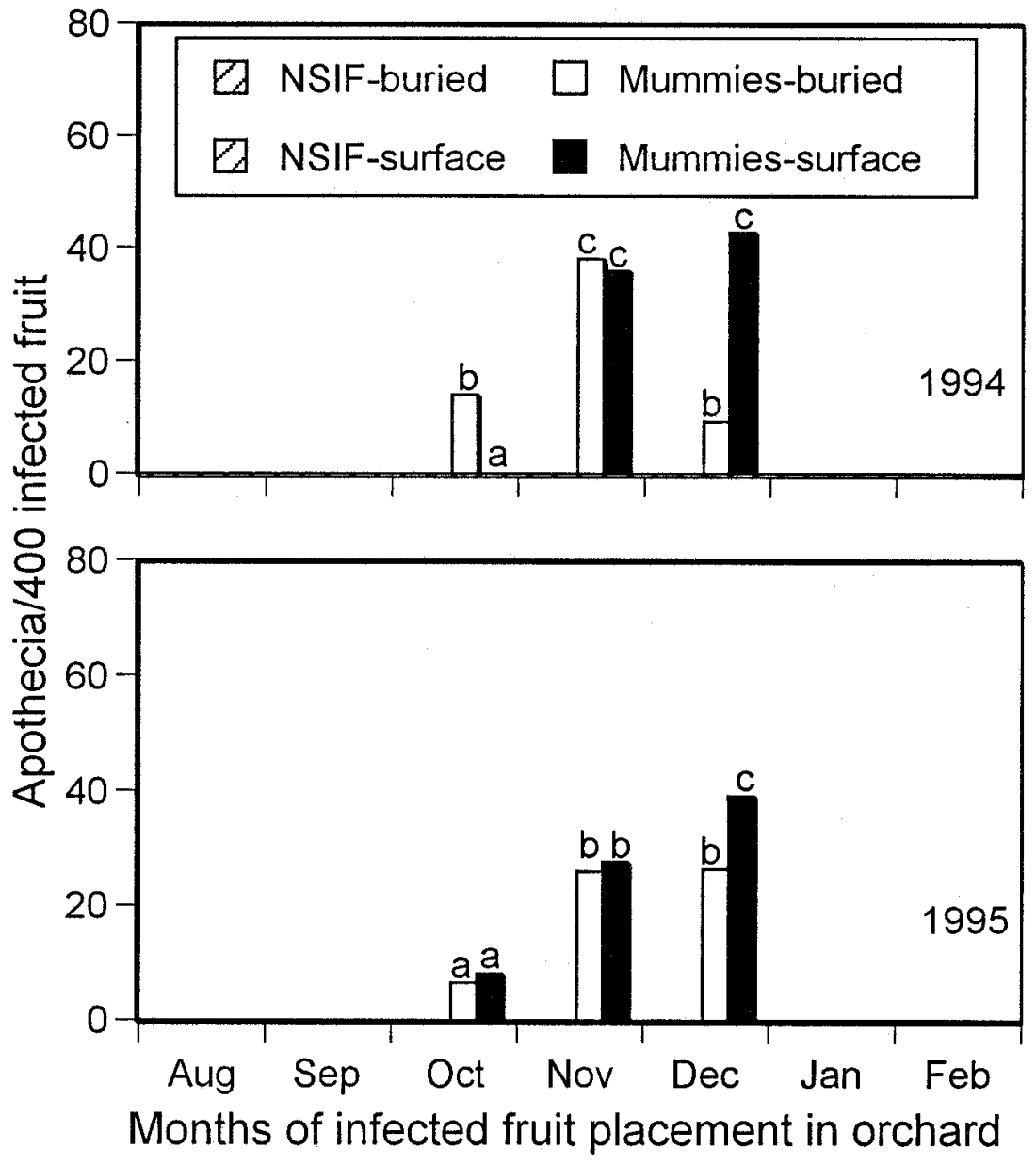

Fig. 1. Mean apothecial production from infected fruit placed in a peach orchard, either on the soil surface or buried 2 to $3 \mathrm{~cm}$, from August to February in 1993-94 and 1994-95. Approximately 400 mummies (mummies-buried or mummies-surface) were placed next to each of six trees each month. Nonstromatized infected fruit (NSIF) (NSIF-buried or -surface) were placed in the orchard in the same manner in only August and September in 1993 and 1994. Plots where infected fruit were placed were examined twice weekly in the spring from 1 February to 15 March 1994 and 1995 for apothecial production. Mean bar values with the same letter are not significantly different (Fisher's LSD, $P$ $=0.05$ ).
$2.5 \mathrm{~cm}$ below the soil surface on 1,13 , and 21 December and 17 January. Three planting flats were used for each treatment on each date, with 150 mummies per flat. Mummies in flats were placed on benches to avoid feeding by rabbits, in a lath house at KAC exposed to the weather. Flats with mummies were examined twice weekly from 1 February to 15 March for the percentage of apothecia produced. Data per flat were cumulative, and apothecia were removed after each examination. Because no significant $(P>0.05)$ differences in apothecial production were determined for mummies placed in December, the results were averaged both years.

Production of apothecia in the laboratory. Laboratory experiments were also conducted to determine more accurately the conditions that favor apothecial production. Approximately 1,440 mummies (15 mummies per container) were partially buried in nonpasteurized commercial sand (3.0 cm height of sand per container) in 96 plastic containers with lids $(32 \times 23 \times 10$ $\mathrm{cm})$. Mummies in containers were incubated for $0,2,3,5,8,11$, and 14 weeks in the dark at $2^{\circ} \mathrm{C}$ and at either $<90 \% \mathrm{RH}$ or $>97 \%$ RH. Distilled water was sprayed on the soil and mummies of each container to maintain 97 to $100 \% \mathrm{RH}$, measured with a temperature-RH sensor (Model XN217, Hygrometrix, Inc., Oakland, CA) and recorded by a datalogger (Model 21X, Campbell Scientific, Logan, UT). Container lids were removed to reduce $\mathrm{RH}$ to $<90 \%$. After each incubation period, four containers were removed for each $\mathrm{RH}$ and incubated again at $15^{\circ} \mathrm{C}$ with a 12 -h photoperiod. In a similar experiment, 180 mummies were placed in 12 containers and incubated in the dark at $2^{\circ} \mathrm{C}$ and $>97 \% \mathrm{RH}$ for 11 weeks, and then incubated again at either 12,15 , or $20^{\circ} \mathrm{C}$ with a 12 -h photoperiod. The percentage of apothecia produced was recorded every 3 days over a 2 -week period after removal from $2^{\circ} \mathrm{C}$. Means were separated by Fisher's least significant difference at $P=0.05$. These experiments were performed twice.

Brown rot incidence in relation to apothecia. Plots $(8 \times 8$ trees $)$ under which mummies were placed were examined for blossom blight during February and March, for latent infections of thinned fruit during April and May, and for fruit brown rot at harvest during July. In the same orchard, there were also randomly arranged control plots $(8 \times 8$ trees $)$ where mummies were removed and none were added. Each treatment was replicated three times. This experiment was performed in 1994, 1995, and 1996.

Blossom blight was assessed (usually twice during the bloom period) in each plot by observing sporulation of $M$. fructicola on 200 blossoms per tree from the four center trees per plot, under which mummies had been placed, and from control trees that received no stromatized fruit. 
The incidence of brown rot blossom blight was calculated for each replicated plot, and means were separated by Fisher's least significant difference at $P=0.05$.

Latent infections of thinned fruit were determined from the four center trees in each plot. One hundred fruit, at the thinning or pit-hardened stage, were collected from trees under which mummies had been placed and from control trees under which no mummies were placed. Fruit were surface sterilized with $0.08 \% \mathrm{NaOCl}, 1.6 \%$ $\mathrm{EtOH}$, and $0.05 \%$ Tween 20 for $4 \mathrm{~min}$, frozen overnight at $-23^{\circ} \mathrm{C}$, and then incubated $\left(21^{\circ} \mathrm{C},>97 \% \mathrm{RH}, 10\right.$-h light cycle) for 7 days in plastic containers. The number of fruit showing M. fructicola conidial sporulation was recorded daily during incubation.

Preharvest brown rot was assessed by observing conidial sporulation of $M$. fructicola on 200 fruit from the four center trees per plot, under which mummies had been placed, and from control trees, under which no mummies were placed, either once or twice before the first fruit harvest.

Postharvest brown rot was also recorded. Fifty fruit with no symptoms of brown rot were harvested from each of the four center trees in each replicate, placed into a cardboard fruit box in two layers with 25 fruit per layer in plastic fruit holders, transported to the KAC Postharvest Laboratory, and stored at $4^{\circ} \mathrm{C}$ for 7 days to restrict Rhizopus rot and simulate commercial cooling storage. The fruit were then incubated at $20^{\circ} \mathrm{C}$ and $>95 \% \mathrm{RH}$. After 3 days, brown rot and other diseases were recorded every other day for 3 to 5 days.

Orchard floor management. In a nectarine (Prunus persica var. nectarina cv. Fantasia) orchard at KAC, apothecia development was studied under two different orchard floor management practices. In one treatment, pre-emergent herbicides Roundup (Ultra-glyphosate, Monsanto Company, St. Louis, MO), Surflan (Dow Elanco, Indianapolis, IN), and Goal 2XL (Rohm \& Haas Company, Philadelphia, PA) were applied to irrigation berms coinciding with tree rows while the orchard floor between rows was rototilled. In the other treatment, no herbicides were applied to tree rows, and the orchard floor was mowed only after blossom petal fall. Each treatment was replicated twice, with 56 trees per replicate. Pre- and postharvest brown rot were assessed in these plots from the four center trees of each replicate as described above. Apothecia were counted under the canopy of the four center trees in each replicate several times during bloom. Treatment means were averaged and separated by Fisher's least significant difference at $P=$ 0.05 .

\section{RESULTS}

Production of apothecia in orchards. In both 1993-94 and 1994-95, apothecia were only produced in February and early March from mummies that had been placed in the orchard in October, November, or December of the previous year (Fig. 1). Apothecia were never produced from nonstromatized, infected fruit. Mummies placed in the orchard in August, September, January, or February did not produce apothecia. In 1994, more apothecia were produced from mummies placed in the orchard during the previous November than from those placed in October or December, and mummies placed on the surface did not produce significantly more apothecia than buried mummies. In 199394, mummies placed on the soil surface in October did not produce apothecia, while in December, significantly $(P<0.05)$ more apothecia were produced from mummies on the soil surface than from mummies that were buried. In 1994-95, more apothecia were produced from mummies that were placed in the orchard in December than from those placed in October or November, and significantly $(P<0.05)$ more were produced from mummies placed on the soil surface than from those buried. For the mummies placed in October or November, there was no significant difference in the number of apothecia produced from mummies buried than from those placed on the soil surface (Fig. 1).

Production of apothecia in a lath house. In lath house experiments, apothecia were only produced from mummies that were placed in December either on the soil surface, partially buried, or completely buried $2.5 \mathrm{~cm}$ below the soil surface (Fig. 2 ). The number of apothecia produced from mummies placed on the soil surface was greater, but differences were not significant. No apothecia were produced from mummies placed in a similar manner in January.

Production of apothecia in the laboratory. In laboratory experiments, apothecia were only produced from mummies that were incubated at $2^{\circ} \mathrm{C}$ and $>97 \% \mathrm{RH}$ in moist sand and in the dark for 8 weeks or longer, and then for 2 weeks at $15^{\circ} \mathrm{C}$ with a 12-h photoperiod. After an 11-week incubation period $\left(2^{\circ} \mathrm{C},>97 \% \mathrm{RH}\right)$, significantly $(P<0.05)$ more apothecia were produced at temperatures of $12^{\circ} \mathrm{C}$ (115) and $15^{\circ} \mathrm{C}(142)$ than at $20^{\circ} \mathrm{C}$ (15 apothecia per 120 mummies).

Brown rot in relation to apothecia. In 1994, there was significantly $(P<0.05)$ more blossom blight, latent infections of thinned fruit, and brown rot at harvest in

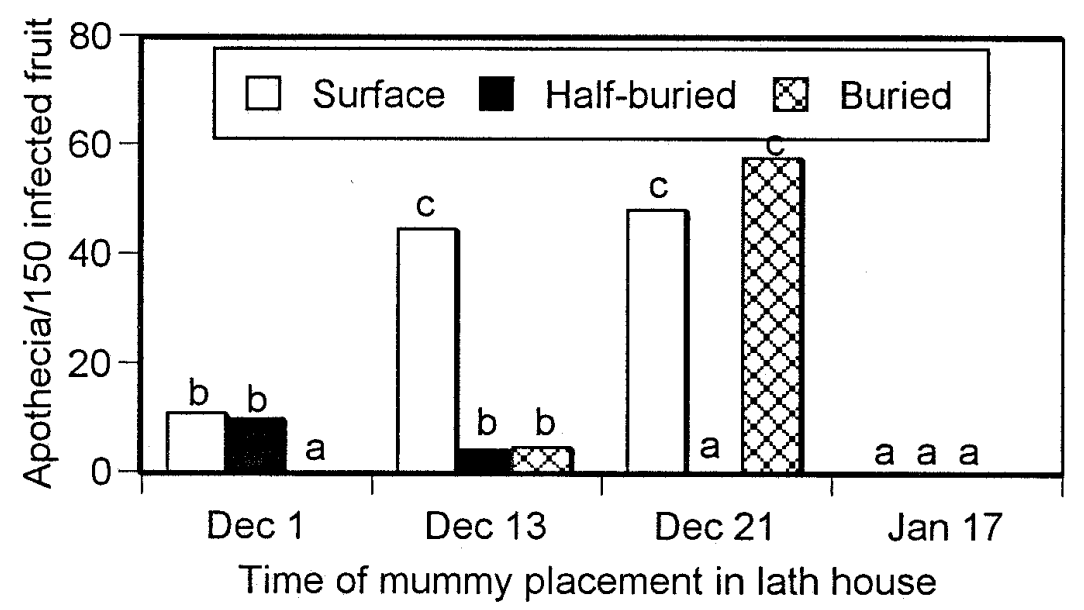

Fig. 2. Mean apothecial production from mummies placed in a lath house, in 1994 and 1995, either on the soil surface, partially buried, or buried $2.5 \mathrm{~cm}$ below the soil surface. Three planting flats were used for each treatment on each date, with 150 stromatized mummies per flat. Flats with mummies were examined twice weekly in the spring from 1 February to 15 March for apothecial production. Data per flat were cumulative and averaged for both years. Mean bar values with the same letter are not significantly different (Fisher's LSD, $P=0.05$ ).

Table 1. Brown rot blossom blight, latent infections of thinned fruit, and fruit brown rot at harvest from tree plots where mummies were either added or removed

\begin{tabular}{lcccccccc}
\hline & \multicolumn{2}{c}{ Blossom blight $(\%)^{\mathrm{w}}$} & & \multicolumn{2}{c}{ Latent infection $(\%)^{\mathrm{x}}$} & & \multicolumn{2}{c}{ Fruit brown rot $(\%)^{\mathbf{y}}$} \\
\cline { 2 - 3 } Year & Added & Removed & & Added & Removed & & Added & Removed \\
\hline 1994 & $0.9 \mathrm{a}^{\mathrm{z}}$ & $0.3 \mathrm{~b}$ & & $3.5 \mathrm{a}$ & $1.9 \mathrm{~b}$ & & $0.4 \mathrm{a}$ & $0.1 \mathrm{~b}$ \\
1995 & $3.6 \mathrm{a}$ & $2.4 \mathrm{a}$ & & $8 \mathrm{a}$ & $1.2 \mathrm{a}$ & & $7.5 \mathrm{a}$ & $3.1 \mathrm{~b}$ \\
1996 & $0.0 \mathrm{a}$ & $0.0 \mathrm{a}$ & & $0.0 \mathrm{a}$ & $0.0 \mathrm{a}$ & & $2.1 \mathrm{a}$ & $1.2 \mathrm{a}$ \\
\hline
\end{tabular}

${ }^{\mathrm{w}}$ Averages from four center trees per plot, 200-blossom replication per tree.

$\mathrm{x}$ Averages from four center trees per plot, 100 -thinned fruit replication per tree.

${ }^{y}$ Averages from four center trees per plot, 200-fruit replication per tree.

${ }^{\mathrm{z}}$ Paired values with different letters within a row differed significantly according to Fisher's least significant difference test at $P \leq 0.05$. 
the plots where mummies had been added than in plots where mummies were removed (Table 1). In 1995, blossom blight and latent infections of thinned fruit on trees above the mummies did not differ significantly when compared with trees from which and under which mummies were removed. There was, however, significantly $(P<0.05)$ more brown rot at harvest in plots with mummies than in plots where the mummies were removed in 1994 and 1995 (Table 1). In 1996, spring weather conditions were warmer and drier during bloom (the second and third week of February) than in 1994 to 1995 (Table 2), and blossom blight and latent infections of thinned fruit were undetectable (Table $1)$.

Mummy removal. In 1993, after a devastating brown rot year, we removed approximately 22,400 mummies (56 fruit boxes at 400 mummies per box) from one 33-ha orchard. Since 1993, the number of mummies removed from this orchard has declined dramatically, with only 600 mummies removed in 1997 (Fig. 3).

Orchard floor management. Apothecia were observed only in the nonherbicide, nonrototilled plots, averaging 2.4 and 2.3 apothecia per tree in 1996 and 1997, respectively. No apothecia were found in the herbicide-treated and rototilled plots. Significantly $(P<0.0034)$ more preharvest brown rot on fruit was observed in the nonherbicide, nonrototilled plots $(2.4 \%)$ than in the herbicide-treated, rototilled plots $(0.6 \%)$. No difference was observed in postharvest brown rot from apparently healthy fruit taken from each treatment and stored under commercial conditions.

\section{DISCUSSION}

This study has shown that in order for M. fructicola to produce apothecia in the San Joaquin Valley, infected fruit must be subject to a drying and incubation period similar to the 5- to 8-month stromatization period described by Willetts and Harada for apothecial production in Japan (32). For $M$. fructicola-infected fruit to produce apothecia in Japan, they must first produce mature stromata, undergoing a stromatization process that involves a 4 - to 8 -week period between 15 and $20^{\circ} \mathrm{C}$, another 4 - to 8 -week period between 20 and $30^{\circ} \mathrm{C}$, and then 3 to 4 months at colder temperatures between 0 and $15^{\circ} \mathrm{C}(31,32)$. In both orchard and laboratory experiments of fruit infected by $M$. fructicola in the San Joaquin Valley, apothecia were produced only from mummies subject to conditions similar to those described above. For example, apothecia were produced only in February and early March from fruit that were infected and mummified in June or July of the previous year and then allowed to dry on the trees for several months until they were either placed on the orchard floor or buried in October, November, or December (mummies-buried or -surface, Fig. 1). Fruit (nonstromatized, infected fruit [NSIF], Fig. 1) that were infected in June, July, or August and had either fallen to the ground or were removed from trees and placed on the soil surface or buried, and not allowed to dry on trees through the warm summer months, never produced apothecia, presumably because they did not have the necessary time to produce mature stromata. Furthermore, infected fruit on the ground in late summer is subject to frequent irrigations, and its decomposition appears enhanced due to high temperatures and soil moisture. Many other fungi, insects, and nematodes rapidly colonize infected fruit when they are on the ground (17). Apothecial production has never been observed on infected fruit still attached to trees, but only on fruit in moist soils $(5,19,26,32)$. Infected fruit that remained on trees and was not placed on or beneath the soil surface until January or February never produced apothecia, although they had the incubation time necessary for stromatization. These infected fruit may have had mature stromata but not the high humidity, which wet soil imparts, necessary for carpogenic germination and apothecial initiation $(31,32)$.

Results from this study provide useful information to stone fruit growers in the San Joaquin Valley who would like to im- plement cultural controls for controlling brown rot instead of relying completely on fungicide spray programs. Brown rot cultural controls would depend primarily on preventing infected fruit from becoming stromatized and eventually producing apothecia or surviving the season and sporulating with conidia $(19,27)$. We have recommended to growers that after the last harvest they examine their trees and dislodge as many of the unpicked fruit as they can, so that the fruit decomposes rather than becoming stromatized. Unfortunately, with dense foliage and the high numbers (900 to 1,000) of fruit per tree, some fruit inevitably remain and later become infected and stromatized.

Most stone fruit growers knock mummies from their trees during December and January when they are dormant-pruning and the mummies are easy to see. Infected fruit left on trees until this time would have had the ideal conditions for stromata development in the fall, and when dislodged in winter, these stromatized fruit or mummies are subject to conducive conditions for apothecial development. We have recommended to growers that when they are dormant-pruning their trees, they should remove these stromatized "winter" mummies from their orchard instead of knocking them to the ground. Our grower cooperators, who initially implemented winter mummy removal programs, spent approximately $\$ 95 /$ ha or about the cost of one fungicide application in 1993 (B. A. Holtz and T. J. Michailides, unpublished data). After several years of mummy removal and an apparent reduction in brown rot and mummies (Fig. 3), our growers and their laborers carry bags on their belts while dormant-pruning, which they fill with mummies and empty into buckets between trees, and later remove from the orchard at a negligible cost. In 1995, when neighboring stone fruit growers experienced a severe brown rot year, our cooperator, who had been removing mummies, had minimal losses (B. A. Holtz and D. Pampaian, unpublished data); we believe this was due in part to the continued re-

Table 2. Climatic conditions during tree fruit bloom periods from 1 February 1994 to 15 March 1996 at Kearney Agricultural Center in Parlier, California

\begin{tabular}{|c|c|c|c|c|c|c|}
\hline \multirow[b]{2}{*}{ Period } & \multirow[b]{2}{*}{ Year } & \multicolumn{2}{|c|}{$\begin{array}{l}\text { Mean daily temperature } \\
\qquad\left({ }^{\circ} \mathbf{C}\right)^{\mathrm{z}}\end{array}$} & \multicolumn{2}{|c|}{$\begin{array}{l}\text { Mean daily relative } \\
\text { humidity }(\%)^{\mathrm{z}}\end{array}$} & \multirow{2}{*}{$\begin{array}{c}\text { Rainfall } \\
(\mathbf{m m})^{\mathrm{z}}\end{array}$} \\
\hline & & Max & Min & Max & Min & \\
\hline $\begin{array}{l}1-15 \mathrm{Feb} \\
15-28 \mathrm{Feb} \\
1-15 \mathrm{Mar}\end{array}$ & 1994 & $\begin{array}{l}14.5 \\
16.5 \\
22.3\end{array}$ & $\begin{array}{l}3.3 \\
4.5 \\
7.5\end{array}$ & $\begin{array}{l}99.4 \\
97.5 \\
94.2\end{array}$ & $\begin{array}{l}57.7 \\
55.8 \\
52.7\end{array}$ & $\begin{array}{r}19.3 \\
28.9 \\
7.6\end{array}$ \\
\hline $\begin{array}{l}1-15 \mathrm{Feb} \\
15-28 \mathrm{Feb} \\
1-15 \mathrm{Mar}\end{array}$ & 1995 & $\begin{array}{l}15.0 \\
16.9 \\
18.6\end{array}$ & $\begin{array}{l}7.3 \\
8.3 \\
9.5\end{array}$ & $\begin{array}{l}98.8 \\
97.9 \\
97.4\end{array}$ & $\begin{array}{l}70.4 \\
68.4 \\
64.3\end{array}$ & $\begin{array}{r}23.4 \\
0.1 \\
117.8\end{array}$ \\
\hline $\begin{array}{l}1-15 \mathrm{Feb} \\
15-28 \mathrm{Feb} \\
1-15 \mathrm{Mar}\end{array}$ & 1996 & $\begin{array}{l}19.3 \\
14.6 \\
19.3\end{array}$ & $\begin{array}{l}9.0 \\
5.0 \\
6.0\end{array}$ & $\begin{array}{l}99.9 \\
99.3 \\
98.5\end{array}$ & $\begin{array}{l}70.6 \\
60.3 \\
53.5\end{array}$ & $\begin{array}{l}3.2 \\
5.2 \\
3.1\end{array}$ \\
\hline
\end{tabular}

${ }^{\mathrm{z}}$ Air temperatures and relative humidity were recorded at 2 and $1.5 \mathrm{~m}$ respectively. Data were obtained from California Irrigation Management Information System. PARLIER.A Station 39 (latitude: $36^{\circ} 36 \mathrm{~min} \mathrm{~N}$; longitude: $119^{\circ} 30 \mathrm{~min} \mathrm{~W}$; elevation: $112.3 \mathrm{~m}$ ).

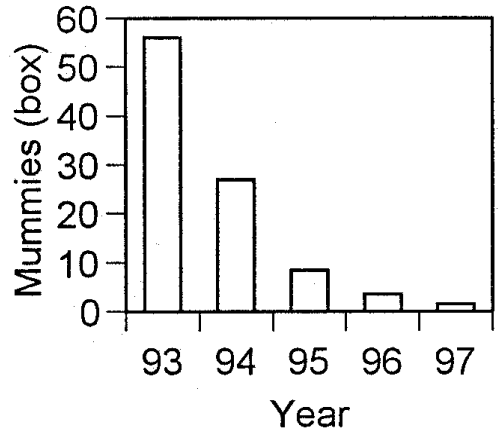

Fig. 3. Number of mummies removed yearly from 1993 through 1997 during dormant pruning from a 33-ha peach orchard in Reedley, California. 
moval of mummies and hence inoculum from the orchard.

Many of the cultural controls recommended by researchers in the early 1900s, such as burying infected fruit below the soil surface, have become established procedures despite conflicting research reports and unsuccessful brown rot control. Ezekiel (9) inoculated peaches and plums with M. fructicola, incubated them for 4 weeks at 28 to $31^{\circ} \mathrm{C}$, and then buried the infected fruit at different soil depths. Because these infected fruit did not produce any apothecia the following spring, he concluded that burying infected fruit below the soil surface inhibits the production of apothecia and recommended plowing infected fruit under for the control of brown rot (9). Growers have followed this recommendation for years, disking or rototilling their orchards immediately after harvest, hoping to destroy infected fruit before they can produce apothecia the following spring.

We believe that the inoculated fruit Ezekial (9) buried did not produce apothecia because $M$. fructicola had not completed the stromatization process and not because they were buried. Other researchers have reported finding apothecia produced on stipes (the stalk of the apothecium) from mummies buried at depths of 6 to $8 \mathrm{~cm}(7,14)$. The stipe serves to raise the fertile disk of the apothecium aboveground for better dispersal of ascospores $(2,16,23)$. Ezekiel (10) and Harrison (13) later found that mummies buried for several years could produce apothecia if returned to the soil surface. We found no difference in the production of apothecia from nectarine and peach mummies that were left on the soil surface or buried $2.5 \mathrm{~cm}$ below (Figs. 1 and 2). In orchards, no apothecia have ever been found coming from mummies left on trees $(6,14,19)$, but only from mummies on the surface or partially to completely buried in moist soils (26) and in situations such as those protected from desiccation by ground foliage (19,32). High soil moisture $(4,7,31)$, low temperatures $(8,10,13)$, high humidity $(2,31,32)$, type and intensity of light $(2,6), \mathrm{pH}$ of soils (3), and the soil depth $(7,14,32)$ at which mummies are buried have all been shown to influence the initiation, development, and maturation of apothecia.

Our results also show that infected fruit on the ground at harvest will not become stromatized, presumably because the fruit will rapidly decompose due to the warm, wet conditions on the floor of an irrigated orchard, and that growers need not disk or cultivate these infected fruit to prevent them from producing apothecia, a costly control measure. Thus, we recommend to growers that infected fruit on the orchard floor after harvest be left undisturbed, because it will decompose before producing either apothecia or conidia the following season (17-19).
In research plots in 1994 and 1995, where hundreds of mummies were added and the plots compared with those where mummies were removed, there was significantly (Table 1) more brown rot in plots with mummies and apothecia. But even though more mummies were placed next to trees than would typically be present in an orchard after a severe brown rot year, differences in brown rot between treatments were not dramatic, and in 1996, we were unable to detect brown rot blossom blight and latent infections. Differences observed in brown rot from year to year are partially due to environmental conditions that can influence disease incidence and severity $(6,27)$. Environmental conditions may also influence whether the production of apothecia or conidia coincides with stone fruit bloom. Norton et al. (26) noted that when stone fruits bloomed early, apothecia were also produced early, and speculated that the environmental conditions that break the dormancy of fruit trees could also influence apothecial development. In 1994 and 1995, most apothecia were produced just ahead of and with stone fruit bloom (10 to 28 February), but in 1996, spring weather conditions were warmer and drier (Table 2), and most of the apothecia observed in our plots emerged and withered before initial stone fruit bloom. We have never observed apothecia in the San Joaquin Valley after stone fruit bloom.

Results of this study also indicate that orchard floor management can reduce the production of $M$. fructicola apothecia and lessen preharvest fruit brown rot. In orchard experiments, apothecia were only observed in nonherbicide and noncultivated (nonrototilled) orchard plots with orchard floor vegetation, while no apothecia were found in vegetation free herbicide-treated and cultivated (rototilled) plots. The physical disruption of the orchard floor during rototilling may disrupt apothecial initiation, preventing apothecial formation and ascospore discharge (15). Also, orchard floors with natural vegetation or cover crops may create a protective habitat for apothecia against desiccation. Thus, growers may also wish to consider orchard floor management practices along with the prevention and removal of mummies as a means of reducing brown rot, instead of relying entirely on fungicide applications, especially with the development of fungicide-resistant pathogen populations $(25,28)$ and heightened environmental concerns over fungicide use.

\section{ACKNOWLEDGMENTS}

We thank R. Kölliker for technical assistance; R. Pampaian and D. Pampaian (Pampaian Packing Corp., Reedley) for providing field sites and removing tree mummies for our experiments; S. Johnson for providing research sites at the Kearney Agricultural Center; and M. Doster and N. Evans for reviewing the manuscript. Our thanks extend to D. Rice for sharing an experimental orchard and to J. Chevalier for support in field experiments. This study was supported in part by the University of California Statewide Integrated Pest Management Project, the California Tree Fruit Agreement, and the California Prune Board.

\section{LITERATURE CITED}

1. Bartram, H. E. 1916. A study of the brown rot fungus in northern Vermont. Phytopathology 6:71-78.

2. Batra, L. R. 1991. World species of Monilinia (fungi): Their ecology, biosystematics and control. Mycologia Memoir No. 16, J. Cramer, Berlin, Stuttgart.

3. Baur, K., and Huber, G. A. 1941. Effect of fertilizer materials and soil amendments on development of apothecia of Sclerotinia fructicola. Phytopathology 31:1023-1030.

4. Baxter, L. W., Jr., Zehr, E. I., and Epps, W. M 1974. A method for inducing production of apothecia of Monilinia fructicola from brown rot-infected stone fruit in South Carolina. Plant Dis. Rep. 58:844-845.

5. Biggs, A. R., and Northover, J. 1985. Inoculum sources for Monilinia fructicola in Ontario peach orchards. Can. J. Plant Pathol. 7:302-307.

6. Byrde, R. J. W., and Willetts, H. J. 1977. The Brown Rot Fungi of Fruits: Their Biology and Control. Pergamon Press, Oxford.

7. Cunningham, G. H. 1922. The significance of apothecia in the control of brown rot of stone fruits. N.Z. J. Agric. 25:225-230.

8. Elliot, M. E. 1965. Some factors in apothecium production of Ciboria acerina in darkness and light. Can. J. Bot. 43:641-645.

9. Ezekiel, W. N. 1921. Some factors affecting the production of apothecia of Sclerotinia cinerea. Phytopathology 11:495-499.

10. Ezekiel, W. N. 1924. Fruit-rotting Sclerotinias. II. The American brown-rot fungi. Md Agric. Exp. Stn. Bull. 271:87-142.

11. Fant, G. W. 1924. The manner of infection of peach twigs by the brown rot fungus. Phytopathology 14:427-429.

12. Free, S. J., Holtz, B. A., and Michailides, T. J. 1996. Mating behavior in field populations of Monilinia fructicola in California. Mycologia 88:208-211.

13. Harrison, T. H. 1922. Note on the occurrence in New South Wales, Australia, of the perfect stage of a Sclerotinia causing brown-rot of fruits. J. Proc. Royal Soc. N.S.W. 55:215-219.

14. Hewitt, W. B., and Leach, L. D. 1939. Brownrot Sclerotinias occurring in California and their distribution on stone fruits. Phytopathology 29:337-351.

15. Holtz, B. A., Hong, C. X., and Michailides, T. J. 1997. Cultural practices which decrease Monilinia fructicola apothecia in the San Joaquin Valley. Phytopathology 87:S43.

16. Honey, E. E. 1928. The monilioid species of Sclerotinia. Mycologia 20:127-157.

17. Hong, C. X., Holtz, B. A., Morgan, D. P., and Michailides, T. J. 1997. Significance of thinned fruit as a source of the secondary inoculum of Monilinia fructicola in California nectarine orchards. Plant Dis. 81:519-524.

18. Hong, C. X., and Michailides, T. J. 1998. Effect of temperature on the discharge and germination of ascospores by apothecia of Monilinia fructicola. Plant Dis. 82:195-202.

19. Hong, C. X., Michailides, T. J., and Holtz, B. A. 1996. Survey of primary inoculum sources of brown rot in stone fruit orchards in the San Joaquin Valley of California. Phytopathology 86:S110.

20. Huber, G. A., and Baur, K. E. 1941. Brown rot on stone fruits in western Washington. Phytopathology 31:718-731.

21. Jehle, R. A. 1913. The brown-rot canker of the peach. Phytopathology 3:105-110.

22. Landgraf, F. A., and Zehr, E. I. 1982. Inocu- 
lum sources for Monilinia fructicola in South Carolina peach orchards. Phytopathology 72:185-190.

23. Leach, L. D., and Hewitt, W. B. 1939. Forced ejection of ascospores from apothecia of Sclerotinia species. Phytopathology 29:373.

24. Michailides, T. J., and Morgan, D. P. 1997. Influence of fruit-to-fruit contact on the susceptibility of French prune to infection by Monilinia fructicola. Plant Dis. 81:14161424.

25. Michailides, T. J., Ogawa, J. M., and Opgenorth, D. C. 1987. Shift of Monilinia spp. and distribution of isolates sensitive and resistant to benomyl in California prune and ap- ricot orchards. Plant Dis. 71:893-896.

26. Norton, J. B. S., Ezekiel, W. N., and Jehle, R A. 1923. Fruit-rotting Sclerotinias. I. Apothecia of the brown-rot fungus. Md. Agric. Exp. Stn. Bull. 256:1-32.

27. Ogawa, J. M., and English, H. 1991. Diseases of Temperate Zone Tree Fruit and Nut Crops. Univ. Calif. Div. Agric. Nat. Resour., Publ. 3345.

28. Ogawa, J. M., Manji, B. T., Adaskaveg, J. E., and Michailides, T. J. 1988. Population dynamics of benzimidazole-resistant Monilinia species of stone fruit trees in California. Pages 36-39 in: Fungicide Resistance in North America. J. C. Delp, ed.
American Phytopathological Society, St. Paul, MN.

29. Roberts, J. W., and Dunegan, J. C. 1924. The fungus causing the common brown rot of fruits in America. J. Agric. Res. 28:955-960.

30. Roberts, J. W., and Dunegan, J. C. 1926 Blossom blight of the peach. Phytopathology 16:217-222.

31. Terui, M., and Harada, Y. 1966. Apothecial production of Monilinia fructicola on artificial media. Trans. Mycol. Soc. Jpn. 7:309 311.

32. Willetts, H. J., and Harada, Y. 1984. A review of apothecial production by Monilinia fung in Japan. Mycologia 76:314-325. 